\title{
Infância em Manuel Bandeira: experiência e linguagem poética
}

\author{
Rosiane de Sousa Mariano Aguiar*
}

\begin{abstract}
Resumo: O presente artigo analisa, principalmente, o Abstract: This article analyzes Manuel Bandeira's poema "Evocação do Recife" de Manuel Bandeira. poem 'Evocação do Recife' (Evocation of Recife) Infância, neste estudo, será compreendida como a conceiving childhood as the prime experience of experiência primordial da linguagem poética Bandeira's poetic language, which in turn is achieved bandeiriana, obtida pelo refinamento estilístico by the symbolic refining of the style and is exercised in alcançado na esfera simbólica e exercida no jogo com word games. The experiences obtained through as palavras. As experiências obtidas através das children's songs, games and rhymes, as well as through cantigas de roda, parlendas, brinquedos, estórias da oral tradition stories-in sum, through collective tradição oral, enfim, da própria memória coletiva da memory itself relating both to its corresponding time época e seus elementos, impregnam a poética de period and to its elements-impregnate Bandeira's Bandeira e são tratadas com olhar diferenciado por ele. poetics and are approached through his peculiar point Nesse passo, é possível também acolher o índice of view. In such a context it is also possible to histórico que pode ser visto no texto literário quando recognize that the poem makes visible a historical neste há práticas que traduzem a memória cultural de index insofar as it expresses practices which translate um povo, demonstrando seus conflitos e valores, bem the memory of folk culture and demonstrates the como, as alegrias e as belezas da cultura brasileira conflicts and values of Brazilian culture, as well as its experienciadas na poesia bandeiriana. joys and beauties experienced in Bandeira's poetry.
\end{abstract}

Palavras-chave: poesia; infância; experiência; Keywords: poetry; childhood; experience; memory. memória.

Tornou-se uma indagação para nós o fato de Manuel Bandeira vincular a infância a sua descoberta da poesia e ao segredo do seu itinerário lírico. É evidente que, ao falar de infância, ele se refere a algo mais que a sua infância factual, cronológica e psicológica, vivida em Recife e Petrópolis. Depois de demoradas e atentas leituras de sua obra, passamos a entender a infância como o caminho para a plenitude poética, muito mais do que uma simples temática.

Neste artigo, a infância será tomada a partir da relação entre Literatura e memória ${ }^{1}$, pois as experiências do cotidiano, sejam vividas, sejam observadas, encerram um repertório inesgotável de emoções que Bandeira condensa em linguagem poética. A esse propósito,

\footnotetext{
* Doutoranda em Literatura Comparada - UFRN. Email: rosy_sm@yahoo.it

${ }^{1}$ Utilizamos o vocábulo memória, de acordo com o conceito trabalhado no Dicionário de Conceitos Históricos, que admite fazer essa uma re-elaboração constante, em um novo contexto imaginativo, das experiências vividas Por ser reconstruída, a memória tem liberdade e possibilidades criativas, aproximando-se, assim, da dimensão artística da palavra poética. (VANDERLEI S., Kalina, HENRIQUE S., Maciel. Dicionário de Conceitos Históricos. São Paulo: Contexto, 2005. p.275).
} 
tomaremos a abordagem de Giorgio Agamben $^{2}$ (2005) para fundamentar essa relação e compreender a poética da infância como um tipo de discurso que recupera a experiência e a transforma em coisa tangível. O poeta é levado a considerar a experiência vivida apenas na medida em que ela cessa de ser obscura para tornar-se expressão lírica. A poesia conduz a linguagem ao estatuto original da experiência apropriando-se dela e constituindo um experimentum linguae para a abertura da significação. Isso é diferente de conceber a infância como algo que precede cronologicamente a linguagem.

Por meio do seu instrumento de expressão, Bandeira transfigurou suas experiências em poesia, recriando a realidade, “outras realidades necessárias, estabelecendo relações sempre novas entre as coisas e o nosso contato com elas, entre o seu mistério e o nosso sentimento, entre a sua realidade e os nossos sentidos." (PENNAFORT, 1980, p. 102). É assim que a poesia da infância aproxima-se da perspectiva da memória ao admitir uma inserção no tempo pelo qual as vivências são articuladas. Em outras palavras, tanto na poesia da infância quanto na memória há uma re-elaboração da realidade vivida pela imaginação.

O contato de Bandeira com a gente humilde do Morro do Curvelo, Rio de Janeiro, ensinou-lhe muitas coisas que, sustentadas na autoridade da escrita, constituíram o substrato de algumas experiências transfiguradas poeticamente. Sobre isso, disserta Davi Arrigucci:

O processo de passagem, delicado e sutil, de um dado factual para a esfera lírica supõe uma afinidade profunda entre o poeta e o aspecto da realidade próxima a que se liga, para que se produza uma escolha tão significativa e ao mesmo tempo tão pessoal e íntima. Mas supõe também o reconhecimento da potencialidade literária da circunstância real, de onde se tira o elemento incorporado à construção poética. Isto decerto implica um modo de conceber a literatura que tende a ir além da mera escolha individual e é em parte determinado pelo momento histórico e pelos rumos gerais da produção literária do tempo. (ARRIGUCCI Jr., 2003, p.52).

Prova disso é que as conversas nas calçadas e as brincadeiras de rua eram práticas suficientes para ensinar uma lição de vida: a experiência se colocava como autoridade. Nas sociedades tradicionais, a autoridade sinalizava a experiência como vivência, mas hoje, nas sociedades contemporâneas, ela é sinal de conhecimento (ciência), de modo que se tornou algo que pode somente fazer e não mais ter. $\mathrm{O}$ viés da infância entra a partir da articulação poética das experiências citadas acima. Ela aparece como a essência mesma a partir da qual a experiência poética do autor é fortalecida.

\footnotetext{
${ }^{2}$ A propósito da relação entre experiência e linguagem, pressuposto para a compreensão da infância como sugere o título do presente estudo, Giorgio Agamben ressalta a idéia do experimentum linguae, conforme suas palavras: "Um experimentum linguae deste tipo é a infância, na qual os limites da linguagem não são buscados fora da linguagem, na direção de sua referência, mas em uma experiência da linguagem como tal, na sua pura autoreferencialidade." (AGAMBEN, 2005, p.12).
} 
Em “Evocação do Recife", poema publicado em Libertinagem (1930), o discurso literário de Manuel Bandeira traz elementos que apontam à dimensão social e fornecem elementos para um modo de ver a cultura popular pondo em destaque a memória do povo e a sua "fala cristalizada", inerente ao texto literário. Trabalharemos, neste artigo, algumas práticas de representação da memória que esse texto poético reúne.

Nesse sentido, a infância vai ser compreendida a partir da relação entre a voz de Manuel Bandeira, sujeito social, e a linguagem do seu exercício literário. Em Infância e História, Giorgio Agamben (2005) considera que a justa expressão para a existência da linguagem está ligada à condição humana da convivência, condição essa nítida no poema em análise. "Raros poemas com a mesma riqueza de substância. Cada palavra é um corte fundo no passado do poeta, no passado da cidade, no passado de todo homem, fazendo vir desses três passados distintos, mas um só verdadeiro, um mundo de primeiras e grandes experiências da vida.”, observa Gilberto Freyre (1980, p.78). A memória coletiva é um lugar onde as experiências do poeta são mediadas lingüisticamente através de sua arte. Bandeira elabora, em discurso literário, suas remotas vivências de Recife. Essa prática é coerente tanto com a essência do exercício poético quanto com a nossa compreensão de infância na obra do poeta, pois de acordo com AGAMBEN (2005) é na linguagem que o sujeito tem a sua origem e o seu lugar. Desse modo, infância e linguagem são convergentes e nelas encontramos o lugar da experiência na literatura do poeta. Quando Bandeira fala de infância, refere-se a um momento em que se constituem suas experiências estruturantes, sua entrada e sua passagem de homem para a vida simbólico-cultural exercida na linguagem.

A voz do poeta é transfigurada em poema (palavra escrita). Ele a utiliza para falar do cotidiano e da experiência comunicável. A produção do poeta está subordinada ao paradigma da fala proferida num tempo histórico, permitindo-nos recuperar práticas de oralidade.

No poema "Evocação do Recife", Bandeira transcreve os pregões dos vendedores de bananas, roletes de cana, amendoins e ovos. A seguinte passagem traz confirmada essa marca de oralidade: "A vida não me chegava pelos jornais nem pelos livros/Vinha da boca do povo na língua errada do povo/ Língua certa do povo" (BANDEIRA, 1977, p.212). É como se Bandeira quisesse elucidar, nesse trecho, que a continuidade da história humana era feita pela fala. Parece coerente essa hipótese, se considerarmos, de acordo com Walter Benjamin (1993b), que o caráter oral da narrativa se dava como a passagem do anel de mão em mão,

\footnotetext{
${ }^{3}$ Segundo David Gonçalves, “as formas simples são uma fala cristalizada e de caráter coletivo. A criação dessas formas realiza uma dupla operação que implica diretamente nas noções de língua e fala, nas mesmas direções de Ferdinand de Saussure." (1981, p.40).
} 
entre gerações. Outro aspecto que nos chama atenção nos versos transcritos é a ausência dos meios de comunicação de massa. BENJAMIN (1993b) acrescenta que a informação, como nova forma de comunicação, vai contribuir para o desaparecimento da narrativa. O filósofo acrescenta que essa oralidade não tinha dimensões de regras e normas da língua padrão. No entanto, era validada, e através dela a vida era narrada de boca em boca, tal como faz o poeta registrando em seus versos a memória coletiva de folguedos, brincadeiras, histórias humanas, pregões, descrição de ruas, rezas e festividades. Paul Zumthor aponta que a oralidade "é a historicidade de uma voz: seu uso" e nos chama atenção para a importante função da voz, "da qual a palavra constitui a manifestação mais evidente.” (1993, p.21). No texto poético de Bandeira, a voz é utilizada para descrever e narrar as práticas de oralidade na época em que "a vida não lhe chegava pelos jornais nem pelos livros". A escrita poética aproxima-se do estatuto da memória porque permite uma leitura da sociedade a partir das práticas desta, entendidas aqui como experiências que se explicitam e aparecem na linguagem. Nisso reside nossa compreensão da infância em Bandeira.

Walter Mignolo (1993) esclarece ser homem sábio aquele que tem experiência para transformar o conhecimento transmissível às novas gerações. Para MIGNOLO (1993), as formas da fala cotidiana, às quais têm acesso todos os membros da comunidade, são discursos que conservam e transmitem a continuidade da História. Isso nos leva a crer que Bandeira cuidou em conservar e em transmitir a memória social, projetando sua energia criativa em poesia.

Para facilitar nossa compreensão, outro aspecto que nos convém ressaltar, a partir dos estudos de Roger Chartier, refere-se às formas dos textos e a sua materialidade, entendendo não só o mundo dos objetos escritos, e também a voz enquanto suporte dessa materialidade, a qual: "nos leva à dimensão de uma leitura histórica dos textos literários, não para reduzi-los a uma condição documental, senão para articular tanto as representações das práticas como as práticas das representações." (CHARTIER, 2001, p. 84).

Dessa forma, o historiador pode recuperar o que foi dito, buscando os indícios em práticas de oralidade no registro escrito. O discurso literário é, portanto, um campo possível onde se buscam as práticas de representações através da memória coletiva que o texto literário pode apresentar, pois se articula com os elementos da realidade material do mundo social. Sobre a relação entre História e Literatura em "Evocação do Recife", comenta Gilberto Freyre:

não se evoca uma cidade sem fazer história; e, quando se é Manuel Bandeira, sem fazer literatura. O poema de Manuel Bandeira é história e é literatura. Mas é acima de tudo poema. É 
de uma grande pureza poética e de uma grande pureza humana, sendo ao mesmo tempo uma crônica, com nomes de gente, de rua, de coisas regionais. (FREYRE, Op. cit., p.78).

A poesia de Manuel Bandeira é um texto que nos comunica o Belo, o encantamento, o mistério e o fascínio em seus aspectos estéticos. Mas também nos fornece, como produtos históricos e sociais, as dimensões do pensamento e da sensibilidade, as quais detêm a dimensão da memória. Raymond Williams (1979) afirma que as formas de manifestação do pensamento, a exemplo da Literatura, não são apenas o reflexo da constituição social, e sim, partes constituintes da própria memória da sociedade. A linguagem poética de Bandeira, nessa perspectiva, é detentora de aspectos da estrutura da memória social, o que inclui festas, conversas, cantigas de roda, feiras, pregões e brincadeiras. Isso não exclui, porém, a dimensão transcendente própria ao texto literário.

\section{$1 \mathrm{O}$ poeta como contador de história}

Em "Meninos Carvoeiros", "Balõezinhos" e "Camelots", o olhar de Bandeira se volta para as coisas simples para perceber seus sentidos específicos, diferente dos passantes comuns, preocupados em alcançar objetivos e ver em tudo um meio para atingi-los.

Tendo vivido na época do desenvolvimento industrial e urbano, seu olhar ora se volta às reminiscências, ora para as experiências simples do cotidiano: conversas nas calçadas, trabalho dos vendedores, agitação das feiras, a dor dos meninos pobres, as brincadeiras das crianças etc. Fala dos acontecimentos, não de forma cientificista, descritiva e factual, impregnando seu texto com experiências cotidianas. Mais uma vez os indícios de historicidade aparecem em sua arte poética, pois a relação que há entre Literatura e memória permite-nos recuperar o sentido dos acontecimentos esquecidos para dar-lhe outras significações. Seus versos sobre os meninos pobres têm certa perspectiva histórica, pois nos transmitem experiências vividas e nos permitem entender o sentido da existência humana.

Esse tipo de olhar poético ao eleger os pobres, as crianças e a vida simples traz à tona um mundo de significado que sem o dizer poético poderia cair na vala comum do esquecimento. Na lírica bandeiriana, a experiência do pobre traz aberturas que enriquecem a narrativa poética, tornando-se válida diante dos que são ignorantes ou inexperientes na transmissão de tais práticas. Esse é o pensamento de um narrador que ocupa espaço na poesia estudada, dando ao eu-lírico o status de espectador em "Balõezinhos", "Meninos Carvoeiros" e "Camelots". A poesia do cotidiano pode ser associada ao ato de observar, que tinha o poeta. 
Portanto, consiste prioritariamente numa prática de representação decorrente da criação literária.

A lição de infância capta o que é verdadeiramente importante na vida: "Os balõezinhos de cor / única mercadoria útil e verdadeiramente indispensável ("Balõezinhos", Ritmo Dissoluto, Op. cit., p.196); os que "sabem mexer nos cordéis com tino ingênuo de demiurgos de inutilidades. / E ensinam no tumulto das ruas os mitos heróicos da meninice...”. Diferentemente ocorre com os "homens que passam preocupados ou tristes" ("Camelots", Libertinagem, Op. cit., p.205), voltados para as complicações infinitas do dia-a-dia e não vêem o sentido da vida porque não compreendem ser as coisas humildes as mais sublimes da existência humana: "existência inteiramente simples e absolutamente grandiosa." (BENJAMIN, 1993b, p. 118).

Falando em lição de infância, não podemos prosseguir sem antes fazermos uma breve parada para afirmar que estamos diante de um poeta que assume a condição de contador de histórias. Esse 'resíduo' ${ }^{4}$ cultural, na lírica de Bandeira, encontra consonância com os aedos, primeiros contadores de histórias. A tradição oral dos aedos é uma prática cultural primitiva em que os poetas cantavam e recitavam ao som da lira, suas canções eram transmitidas de geração a geração. Bandeira comporta-se como narrador em seu fazer literário como se depreende na forma transmissível da memória coletiva. Nos poemas em análise, Bandeira nos comunica experiências vividas e observadas. Esse aspecto é apontado por Benjamin para identificar o verdadeiro narrador. Esse filósofo afirma que é narrador quem pratica a forma transmissível das vivências cotidianas. As experiências são comunicáveis no âmbito poético, pois ao falar de memórias individuais e coletivas o poeta nos transmite o caráter exemplar dessas histórias, sendo capaz, como no poema "Camelots", de nos deixar uma moral, característica específica da narração.

Agarrando-se ao sutil, Bandeira, assim como um contador de histórias, realiza um movimento que busca reminiscências e lembranças do vivido. Narra com as mãos e os olhos a força da ação do homem, trazendo à luz a ausência de razão das disparidades sociais, como ocorre no poema "Meninos Carvoeiros". Essas reminiscências, para ele, são ruínas que visita e onde recupera certos 'resíduos' significativos, transformando-os em essência poética. $\mathrm{O}$ sentido buscado está na aura lírica que re-significa a História e a existência humana.

\footnotetext{
${ }^{4}$ Empregamos este termo, conforme os estudos desenvolvidos pelo pesquisador Roberto Pontes, segundo o qual admite ser resíduo "aquilo que remanesce de um tempo para outro, podendo significar a presença de atitudes mentais arraigadas no passado próximo ou distante”. (2003. p. 88. Nota 3).
} 
Bandeira parece saber tanto disso, que utiliza mais um artifício de narrador ao recontar histórias do seu povo. Dessa forma, propicia a reconciliação dos homens com a sua existência. BENJAMIN afirma: "Contar a história é a arte de contar de novo." [...] "a narrativa se perde quando as histórias não são mais conservadas." (1993b, p.205). Do mesmo modo, a narrativa poética de Bandeira recria as experiências humanas em continuidade para gerar nova significação. O poeta busca incansavelmente aquilo que se conserva em sua memória, as lembranças da meninice e a recordação das histórias, como se tem no célebre verso: "Rosa vinha me contar" para compor vários poemas que trazem quadrinhas do imaginário popular, a exemplo de "Na Rua do Sabão". A infância em Bandeira remete à experiência e esta à narração e ao discurso poético. O poeta enquanto contador de histórias observa as ruas, procurando um diferencial para sua produção poética, buscando nas narrativas líricas, o fio da significação da existência, a fim de transmitir às gerações futuras seu aprendizado, que através da infância e da ternura para com os pobres, enriqueceu sua experiência poética, conforme confessa no Itinerário de Pasárgada:

Quanto ao morro do Curvelo, o meu apartamento, o andar mais alto de um velho casarão quase em ruína, era, pelo lado dos fundos, posto de observação da pobreza mais dura e mais valente, e pelo lado da frente, ao nível da rua, zona de convívio com a garotada sem lei nem rei que infestava as minhas janelas, quebrando-lhes às vezes as vidraças, mas restituindo-me de certo modo o meu clima da meninice na Rua da União em Pernambuco. Não sei se exagero dizendo que foi na Rua do Curvelo que reaprendi os caminhos da infância. Lá escrevi quatro livros... (BANDEIRA, Op. cit., p.60).

Estamos falando, portanto, do poeta que, não obstante soubesse de cor Os Lusíadas e tivesse acumulado leituras de Goëthe, Heine, Lenau, Mallarmé, La Fontaine, e Taine, havendo recebido influências de Debussy e se acompanhado de Villa-Lobos e Jaime Ovalle, dentre outros, impregnou-se a fundo da raiz poética, da tradição de sua terra, contando histórias de seus conterrâneos, flagrando o "realismo da gente do povo." Sua obra resultou, segundo Arrigucci Jr. (2003), da "formação de uma ampla experiência humana e artística, de um grande cabedal de leituras e uma intensa prática poética.” (Op. cit., p.203).

O enraizamento na memória coletiva e popular dinamizou a criatividade que inaugurou o novo na poesia de Bandeira, o fez ver diferente, arriscar, fugir dos padrões estabelecidos e dar vida à obra poética a partir desse mergulho social que converte a experiência em linguagem. Essa articulação é a novidade na poética analisada, na qual esse experimentum linguae relaciona infância e escrita, dando lugar à ruptura ao quebrar o formalismo poético e encontrar a metáfora certa na plenitude criativa.

\footnotetext{
${ }^{5}$ Expressão usada por Bandeira em Itinerário de Pasárgada, (1954, p.35).
} 
A narrativa poética capta as experiências que estão em via de extinção, porque elas não estão sendo mais intercambiadas, mas a poesia, como lugar que vence as contrariedades, precisa do ir e vir do verso, elemento que impulsiona o fio da escrita, constituindo uma repetição que é vencida pela continuidade. Conquanto a contrariedade não gere a passividade, admite o ato de suportar para haver repetição e conservação pela palavra poética. Conforme afirma Walter Benjamin:

\begin{abstract}
O narrador pode recorrer ao acervo de toda uma vida (uma vida que não inclui apenas a própria experiência, mas em grande parte a experiência alheia. $\mathrm{O}$ narrador assimila à sua substância mais íntima aquilo que sabe por ouvir dizer). Seu dom é poder contar sua vida; sua dignidade é contá-la inteira. (BENJAMIN, 1993b, p.221).
\end{abstract}

As palavras de Walter Benjamin, acima, reiteram nossa convicção de que, na lírica bandeiriana, o espírito sensível de um homem conta histórias para dar significação à complexa existência humana.

\title{
20 Mito do Eterno Retorno e a re-significação dos fragmentos
}

Voltemos a "Evocação do Recife", o poema encomendado, conforme diz Bandeira, por tê-lo concebido mediante um pedido de Gilberto Freire ${ }^{6}$ para o aniversário de Pernambuco. Vejamos a primeira estrofe desse poema:

\author{
Recife \\ Não a Veneza americana \\ Não a Muritsstad dos armadores das Índias Ocidentais \\ Não o Recife dos Mascates \\ Nem mesmo o Recife que aprendi amar depois - \\ Recife das revoluções libertárias \\ Mas o Recife sem história nem literatura \\ Recife sem mais nada \\ Recife da minha infância ${ }^{7}$
}

Mas como ele poderia dirigir-se ao lugar onde reinava sua mitologia?

Abriu-se, então, para a feitura do poema, o momento em que ele tomava posse do território natal mediante rituais de evocação, repetindo, de forma simbólica, a vontade de criação. Há uma série de elementos metafóricos e atemporais, cujo intento é a abolição do tempo passado, a restauração do instante primeiro e a repetição do ato cosmogônico.

\footnotetext{
${ }^{6}$ FREYRE, Gilberto. "Manuel Bandeira, Recifense". In: Perfil de Euclides e outros perfis. Rio de Janeiro: José Olímpio, 1944; Manuel Bandeira: Seleção de textos - Coletânea organizada por Sônia Brayner - Rio de Janeiro: Civilização Brasileira; Brasília: INL, 1980 (Coleção Fortuna Crítica). p. 76.[0]

${ }^{7}$ BANDEIRA, Manuel “Evocação do Recife”. In: Poesia completa e prosa. RJ: Nova Aguilar, 1977. p.212[0].
} 
A partir do título "Evocação do Recife", vemos a atitude reverencial, preparação do tom ritual que abre e fecha o poema sobre o lugar sagrado. Evocar significa chamar almas do outro mundo, ou presentificar lugares, objetos, paisagens, afetos, enfim, uma ação mítica concebida pelo poeta. $\mathrm{O}$ primeiro verso, que singulariza esse chamado, anuncia a verdadeira Recife, concebida no poema em prosa mais longo de sua obra. Não é a cidade conhecida por todos, com suas histórias reais de luta e literatura. No poema de Bandeira, tem-se um Recife sem lugar-comum e sem heróis conhecidos. Temos assim uma identificação do Recife de que Bandeira falará: o das palavras.

Então cada verso - palavra que etimologicamente significa retorno - recoloca a questão do princípio, como se a cada passo o poema arriscasse a não tomar forma; o poeta, a perder-se de si mesmo; a poesia, a não ser. É que o poeta parece forçado a reinventar-se a cada instante, na busca de si mesmo, do poema e da poesia. É por essa experiência profunda que toma rumo e passa sua vida. (ARRIGUCCI Jr., Op. cit., p.46).

No verso "Recife sem mais nada", Bandeira, depois de recusar as possibilidades que apontavam para um Recife factual, pontua a abertura para a vertente ficcional. A cidade à qual o poema passa a se referir é a mitológica, preenchida de poesia, pois o nada nos diz que será pura ficção. Se recorrermos à expressão que também inicia a exuberante narrativa de Guimarães Rosa, Grande Sertão: Veredas, teremos a palavra "Nonada"8, ou seja, nada será real ao longo da narrativa, tudo será ficção. Além disso, detectamos mais uma vez o pronome indefinido 'nada' marcando a lírica de Bandeira. Dessa vez, ele vem desmentir todos os que anunciam a poesia como espelhamento social e dizer que Recife será da infância, da inventividade e das brincadeiras com a linguagem. Um Recife recriado e mitificado pelo dizer poético.

Dito isso, passemos a segunda estrofe do poema em pauta:

A Rua da União onde eu brincava de chicote-queimado e partia as vidraças [de dona Aninha Viegas

Totônio Rodrigues era muito velho e botava o pincenê na ponta do nariz

Depois do jantar as famílias tomavam a calçada com cadeiras, mexericos,

A gente brincava no meio da rua

[namoros, risadas

Os meninos gritavam:

Coelho sai!

Não sai! (BANDEIRA, 1977, p.212)

A primeira prova da instauração do mito é a Rua da União, que integra uma mitologia testificada em Itinerário de Pasárgada e nos fornece mais uma evidência de que a infância é a matéria fundante da criação poética de Bandeira. Não nos importa se tudo que há no poema

\footnotetext{
${ }^{8}$ ROSA, Guimarães. Grande Sertão: Veredas. São Paulo: Círculo do Livro, 1984. p.7.
} 
foi vivenciado pelo menino-poeta, pois a realidade da linguagem é válida no universo criativo da palavra. Bandeira criou o Recife da infância através da "narrativa que brota e recupera os feitos dos nossos heróis fundadores," "9 aqueles que estavam em sua memória e eram os heróis do Recife poético. Foi lá que se construiu seu universo mitológico. E com base mesmo nas palavras de Bandeira temos que admitir sua galeria mitológica: "um Totônio Rodrigues, uma D. Aninha Viegas, a preta Tomásia, velha cozinheira da casa do meu avô Costa Ribeiro, têm para mim a mesma consistência heróica das personagens dos poemas homéricos." (BANDEIRA, 1977, p.35).

Com isso, o poeta torna permanente o sentido da herança cultural e dos mitos da criação através da escrita poética. Somente no lugar da memória cultural e da linguagem, a alma de cada povo, o espírito de cada nação, encontram sua resposta verdadeira. O sentido que extraímos disso é o das experiências que dão suporte à vida. A infância, nessa perspectiva, está ligada a um Recife 'residual', por exprimir-se e por fazer-se; por isso, é um "Recife sem mais nada", conforme as palavras do poeta.

A tradição é a fonte que alimenta os sonhos. Na concepção de KRENAK (1992), esse sonho é entendido como casa da sabedoria, ou seja, está no plano da arte, do conhecimento, da memória e da linguagem. O sonho comunica e é o lugar da cultura. Só assim, o poeta é capaz de recuperar a memória da criação do mundo onde o fundamento da vida e o sentido do caminho do homem no mundo é contado de geração a geração. Para Sônia Brayner, Bandeira "É o poeta que fala pela alma de seu povo, interpreta os sentimentos e aspirações de sua tribo, exprime-se na língua de todos." (1980, p.9).

Bandeira começa, a partir da segunda estrofe, a evocar o palco, as personagens e os atos que tomarão fôlego poético, moldados pela experiência 'cristalizada'. Ela se agiganta e se universaliza pelo poder instaurador da palavra. Esse poder possuidor de rituais e força criadora é atribuído ao ser que cria por recorrer à memória. A infância aparece sempre nos momentos de transposição lingüística e, toda vez que houver uma experiência a partir dali, morrerá o real e se abrirá o simbólico.

A memória, que recria experiências no âmbito significativo da poesia, foi alcançada, muitas vezes, pela experiência da escuta da meninice. É assim que temos versos como os das cantigas de roda:

À distância as vozes macias das meninas politonavam:

\footnotetext{
${ }^{9}$ No artigo, “Antes, o mundo não existia" Ailton Krenak considera que o fundamento da vida está na recuperação da memória da criação do mundo e graças a essa memória informamos nossa arte e nosso conhecimento universal. (1992, p.201).
} 


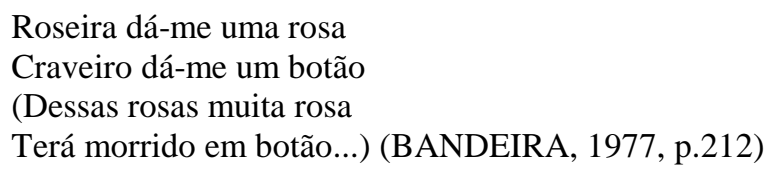

Além de "Evocação do Recife", a recorrência das brincadeiras e cantigas de roda aparece nos poemas "Na rua do sabão", "O anel de vidro", "Boca de forno", "Trem de ferro" e "Rondó do capitão", com as substâncias que deram força à escrita poética. Nesses poemas, os versos, que apresentam cantigas de roda, são 'resíduos' de costumes, brincadeiras, histórias e mitos que provieram não só da cultura do Nordeste, mas de outras épocas e povos, a exemplo do imaginário peninsular, provençal, indígena e africano. ${ }^{10}$ Afrânio Coutinho observa que:

O lirismo brasileiro mergulha suas raízes até as trovas populares, cantadas pelos primitivos trovadores da cidade e do sertão, quando o homem simples, que começa a aglomerar-se na Colônia, procurava expandir suas alegrias ou manifestar seus temores diante de fatos novos, às vezes hostis, que a natureza lhes punha diante, sugestionando-lhes a imaginação. (2002, p.93).

A quadrinha, que está nos versos da evocação, é uma forma simples e rimada que empresta leveza e musicalidade ao verso-livre. A imaginação de Bandeira estava em Recife na feitura que evoca essa cidade, pois, ao passo que desenvolvia a narrativa, parecia estar escutando a cantiga popular. A musicalidade tão marcante na poética da infância, em Bandeira, encontra ressonância com os antigos aedos. O primeiro contato de Bandeira com a poesia deu-se sob a forma de versos dos contos da carochinha, cantigas de roda, trovas populares, coplas de zarzuelas, enfim, versos de toda a sorte os quais lhe ensinava seu pai, como declara o poeta. Desse modo, a lírica Bandeiriana assume novamente o caráter 'residual' porque nela encontramos 'sedimentos mentais' e recursos formais da cultura oral do Nordeste oriunda de outras culturas, recursos estes incorporados oportunamente à sua escrita poética moderna.

Então o mito do retorno, em Bandeira, vai aparecer nos rituais de repetição como é o caso das fogueiras, da prática de soltar balões, das cadeiras nas calçadas e das brincadeiras de roda que aparecem em seus versos. Ou seja, no plano da linguagem, são imagens memorativas que guardam seu significado e seu mistério. As experiências poéticas na lírica de Bandeira se apresentam fragmentadas para o aproveitamento lingüístico à base do 'resíduo' pois: "Assim, certas experiências, significados e valores que não se podem expressar, ou verificar substancialmente, em termos da cultura dominante, ainda são vividos e praticados à

\footnotetext{
${ }^{10}$ Raymond Williams considera que "Qualquer cultura inclui elementos disponíveis do seu passado, [...] certas experiências, significados e valores [...] são vividos e participados à base do resíduo." WILLIAMS, Raymond. “Dominante, residual e emergente". (1979, p.125).
} 
base do resíduo - cultural bem como social - de uma instituição ou formação social anterior." (WILLIAMS. 1979, p.126).

Massaud Moisés entende que "núcleo residual" de uma obra constitui "um gigantesco núcleo de Urânio a irradiar força." É o que resta culturalmente e dá ao autor "o talento de abranger o eterno ou o permanente através do fluxo da História.” (1983, p.320).

Depois da transcrição da quadrinha popular, a narrativa poética é interrompida para mais uma prática de representação que envolve religiosidade, costumes e infância. Vejamos os versos:

De repente

nos longes da noite

Uma pessoa grande dizia:

um sino

Fogo em Santo Antônio!

Outra contrariava: São José!

Totônio Rodrigues achava sempre que era São José.

Os homens punham o chapéu saíam fumando

E eu tinha raiva de ser menino porque não podia ir ver o fogo (BANDEIRA, 1977, p.212)

Bandeira queixa-se de certas limitações que a infância tem, e aponta um ritual religioso, anunciado pelas badaladas de um sino. Ora, se para a tradição cristã o sino representa um anúncio de um acontecimento importante ou o início de uma solenidade religiosa, no poema de Bandeira, esse trecho anuncia que algo digno de reverência será dito na estrofe seguinte, a saber o grande palco de Recife convertido em reinado mitológico. Assim como um rei proclama um decreto na posse de um território, Bandeira delimita seu reinado com quatro ruas de sua infância, constituindo sua mitologia:

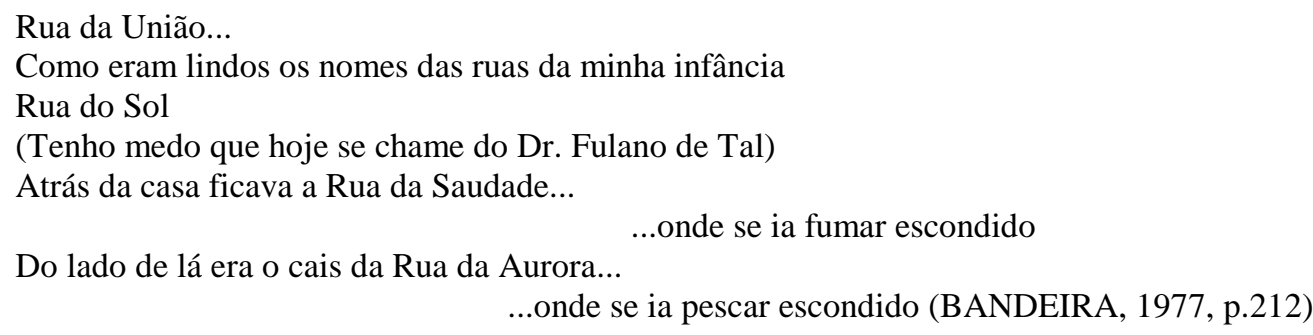

Diz o poeta em Itinerário de Pasárgada: “A Rua da União, com os quatro quarteirões limitados pelas ruas da Aurora, do Sol, da Saudade e Princesa Isabel, foi a minha Tróada; a casa de meu avô, a capital desse reino fabuloso.” (BANDEIRA, 1977, p.297). Davi Arrigucci observa sobre a passagem referida:

De alguma forma, para ele, o poético pode brotar dessas raízes fundas da infância, de uma terra encantada da memória, pois por vezes as imagens aí sedimentadas se revelam carregadas de 
uma emoção distinta das emoções comuns, uma emoção imantada, cuja força de atração se traduz em sua capacidade de instaurar um mundo, articulando os elementos mais heterogêneos em torno de seu pólo essencial. (ARRIGUCCI Jr., Op. cit., p.203).

A infância surge como um novo campo de significação em seu universo poético, o Recife será inteiramente o da Rua da União transfigurado em reino fabuloso. Bandeira evoca a infância para compor seu universo mitológico nas ruas das brincadeiras da meninice. A poesia de Manuel Bandeira é de intensa emoção e reveladora da força poética trazida da infância. A Rua da Aurora, citada por Manuel Bandeira, conota os verdes anos que inscreveram Bandeira no mundo da poesia. Depois da Rua da Aurora, Bandeira reforça a idéia e aponta a Rua do Sol: estrela que iluminou seu exercício poético, pois essa energia captada da aurora da vida garantiu a permanência da Estrela da vida inteira (1986), constituindo inteiramente sua poesia, pois é o título da coletânea que reúne sua obra poética. Em "Profundamente", o poeta adormece à luz das fogueiras de São João, essa luz o desperta para o sentido das brincadeiras, das risadas e das "mais puras alegrias" da meninice captadas pela palavra, tornando-se "núcleo da poesia, através das vozes da infância que contavam histórias no calmo seio da eternidade." (BANDEIRA, "Contrição”, 1977, p.233.)

É nesse ponto que se dá o Mito do Eterno Retorno em Bandeira, pois o ciclo cósmico tem seus extremos num crepúsculo e numa aurora. Lembramos, aqui, do Mito da Fênix que também se encerra na idéia de crepúsculo para abrir-se numa nova aurora.

Para Mircea Eliade (2004), cada ato de criação abre um começo absoluto, restaura o instante inicial, exige um retorno simbólico a esse instante, que é atemporal, e assegura a plenitude primordial que se espera para garantir a realização perfeita de cada ato criador.

A Rua da Saudade guarda uma idéia que faz de Bandeira um narrador melancólico, ao se embeber de lembranças, no lento processo de passagem à linguagem, quando capta o esquecimento, "como se fosse preciso um contato com o ser para, no recolhimento, restituir em poesia o que se foi", nas palavras de Arrigucci Jr. (2003, p.46). Segundo o crítico, "Parece uma volta obrigatória à 'fonte escondida', ao momento primeiro da criação ou do encontro, que revém na perplexidade do instante decisivo, como um recomeço necessário e incerto." (ARRIGUCCI Jr., 2003, p.46).

Por último, fechando a Tróada, a comprovação do reino absoluto: Rua Princesa Isabel. Não há reino sem príncipe, ou princesa e sem castelo, pois a casa do avô, como capital do reinado, só pode ser o castelo das travessuras de Bandeira. O poeta traz no imaginário a Princesa que decretou a libertação dos escravos. Realmente, não poderia ser outra que simplesmente se guarda esperando seu príncipe, mas a que acabou com o aprisionamento dos 
trabalhadores oprimidos e submissos aos seus senhores. Bandeira, na poesia, fez-se senhor de si. Não admitiu que sua poesia se submetesse às normas acadêmicas e aos padrões fixos. $\mathrm{O}$ Recife mitológico acolhe a libertação no fazer, aceita o trabalho por criatividade e inventividade própria, é reinado em que cabem as travessuras dos meninos que faziam coisas proibidas. Bandeira achou, na Rua Princesa Isabel, as libertinagens necessárias para o fazer artístico, era lá que seu imaginário alçava-se em busca de novas descobertas para o universo criativo e poético, escolhendo a infância como a garantia que lhe restituía sempre o segredo desse fazer.

Todas as ruas sugerem um círculo em torno da Rua da União, num eixo que sustenta a idéia do Mito do Eterno Retorno, dando ênfase à narrativa humana pela palavra poética que não tem fim. A Rua da União concentra toda a criação do reino fabuloso de Bandeira, pois, à medida que vai recriando as práticas de representações, evoca, primeiramente, a Rua da União como lugar que deu origem a essas práticas. É de lá que inicia sua fala, lugar da passagem para o mundo da significação lingüística, toda vez que quer intermediar experiências. Mircea Eliade considera que toda criação urbana teve início a partir de um centro, como forma de iluminar as cidades sagradas (centros do mundo). (cf. ELIADE, 2004, p.23). Dali emanam forças criativas, produtivas que alimentam, no caso, a concepção de infância como centro da poesia.

\section{0 sertão na palavra poética}

Nesse passo, quando Bandeira fala em sertão, significa pensar no retorno à raiz de sua experiência poética, que justamente reconhecia, nas experiências que deram sustentáculo à criatividade e "nas voltas inesperadas da emoção do passado, a fonte primeira da poesia. Ele podia, assim, reaprender os caminhos da infância distantes e debruçar-se sobre o grande mundo, para o qual, já está maduro e experiente.” (ARRIGUCCI Jr., Op. cit., p.203).

O sertão é mais uma abertura para a compreensão da infância e da memória na lírica de Bandeira, pois faz parte das experiências que o poeta foi aprendendo a associar à poesia. Prova disso, além dos versos seguintes de "Evocação do Recife", é que esse mesmo "sertãozinho de Caxangá" é listado como um lugar onde também se construiu parte da sua mitologia. (BANDEIRA, 1977, p.35). Leiamos o trecho:

Capiberibe

- Capibaribe

Lá longe o sertãozinho de Caxangá

Banheiros de palha 
Um dia eu vi uma moça nuinha no banho

Fiquei parado o coração batendo

Ela se riu

Foi o meu primeiro alumbramento

Cheia! As cheias! Barro boi morto árvores destroços redomoinho sumiu

E nos pregões da ponte do trem de ferro os caboclos destemidos em jangadas de bananeiras Novenas

\section{Cavalhadas}

Eu me deitei no colo da menina e ela começou a passar a mão nos meus cabelos

Capiberibe

- Capibaribe (BANDEIRA, 1977, p.212)

A infância mais uma vez assume dimensão histórica, principalmente, porque a idéia de História liga-se a de memória, a de fragmentos de experiências vividas e não há uma tradição oficial linear e abstrata. Bandeira, nos versos acima, recupera os 'resíduos' de experiências detentoras de substancialidade a partir da concepção de um princípio original, de raízes que conservam a essência de práticas de representação como é o caso dos "banheiros de palha", das "novenas", dos "redemoinhos" e do "trem". O poeta não concentra sua mitologia somente na Rua da União e na Tróada, sua imaginação é capaz de alcançar "Lá longe o sertãozinho de Caxangá", a fim de re-significar, através da palavra poética, um universo que conta experiências de pessoas "acordadas", banhos de riacho, cadeiras na calçada, estórias contadas e cirandas como práticas que nos fazem saber de um lugar onde são guardados os 'resíduos' que povoam a memória de cada brasileiro. Sulamita Vieira concebe essa noção do sertão como algo construído, experiência, vida e representação. (cf. VIEIRA, 1999, p.23). A estrofe de "Evocação do Recife" condensa descobertas, vivências culturais típicas do contexto social, geográfico e histórico do sertão brasileiro, a saber: as descobertas da nudez do sexo oposto pelas brechas dos banheiros de palha, as cheias nas invernadas, os redemoinhos também registrados no Grande Sertão: Veredas, o trilho do trem, novenas, religiosidade nas festas das cavalhadas. Depois, o poeta desperta e repousa no colo acolhedor de sua cidade mitológica. De novo, a seqüência Capiberibe/ Capibaribe retoma o processo cíclico da narrativa poética.

A palavra lírica de Manuel Bandeira re-significa os valiosos fragmentos das raízes de sua experiência literária ao buscar as substancialidades que nutrem o sentido cultural da vida. O poeta teve tanta lucidez, que confessa nos versos de "Trem de ferro" haver nascido no sertão Ouricuri, cidade do interior de Pernambuco:

Vou mimbora vou mimbora

Não gosto daqui

Nasci no sertão

Sou de Ouricuri (BANDEIRA, 1977, p.236.) 
Não nos importa saber, nesta análise, de fatos biográficos do autor de "Vou-me embora pra Pasárgada", mas vale a pena ressaltar que, conforme notas de sua vida, ele nasceu em Recife, capital do estado e não no interior. Por isso, confessa na epígrafe feita para Estrela da Vida Inteira (1986), ser a "Poesia, minha vida verdadeira." Então o eu-lírico nasceu no sertão, pois foi um contador de histórias de experiências humanas, constituiu sua mitologia com personagens humanos, seres lendários e estava sempre buscando a memória cultural e as raízes que estruturaram suas experiências literárias.

O poema "Trem de ferro" começa com o verso "Café com pão" retirado do material etimológico, popular e coletivo, que produz musicalidade através de repetições e aliterações e a velocidade dos versos sugerindo metaforicamente o trem. Tudo isso nos dá a entender o eulírico cansado do ritmo da vida na cidade e ansioso pelo retorno ao interior de Pernambuco. $\mathrm{O}$ tesouro afetivo que Bandeira re-significou a partir das reminiscências da infância é a própria poesia. A memória do sertão acolhe o sentido da infância em Bandeira, pois nas duas esferas, há a dimensão de criatividade e a de recuperação de experiências transformadas em linguagem artística. Os 'resíduos' culturais do sertão vêm re-significados lingüisticamente em palavra poética.

De fato, o sertão guarda em si a dimensão antropológica enraizada nas tradições. É, ainda, o lugar em que se narram as experiências comunicáveis e se constitui num vasto território mitológico. Ora, a respeito do sertão, acrescentamos o que Ivone Cordeiro Barbosa explica na obra Sertão: um lugar incomun (2000):

\footnotetext{
A palavra sertão guarda um enorme poder de evocação de imagens, sentimentos, raciocínios e sentidos que em torno dela foram sendo substituídos ao longo da experiência histórica brasileira. [...] Sugere, ainda, conteúdo cultural, ao designar um determinado espaço como lugar de tradições e costumes antigos, enfim, naquilo que é concernente às experiências históricas vividas nesse espaço em que a força simbólica do sertão mais se faz sentir. (BARBOSA, 2000, p. 33).
}

Numa passagem das Crônicas da província do Brasil (1936), Bandeira argumenta que a poesia do sertão está posta dentro dos temas populares. Não só na estrofe que pauta o sertão, mas em quase todo o poema "Evocação do Recife", a cultura popular demonstra a identificação da memória nacional que serviu de sustentáculo para a inspiração poética do Pernambucano.

\section{Fim da evocação}


Para finalizar a análise do poema e o nosso estudo, vejamos a próxima estrofe de "Evocação do Recife", na qual Manuel Bandeira evocará novamente uma rua de sua infância para impulsionar a passagem de outras experiências. Nelas há a certeza de que o registro dos indícios da fala do povo guarda a essencialidade da memória coletiva e da História humana. Eis os versos:

Rua da União onde todas as tardes passava a preta das bananas

Com o xale vistoso de pano da Costa

E o vendedor de roletes de cana

$\mathrm{O}$ de amendoim

que se chamava midubim e não era torrado era cozido

Me lembro de todos os pregões:

Ovos frescos e baratos

Dez ovos por uma pataca

Foi há muito tempo...

A vida não me chegava pelos jornais nem pelos livros

Vinha da boca do povo na língua errada do povo

Língua certa do povo

Porque ele é que fala gostoso o português do Brasil

Ao passo que nós

$\mathrm{O}$ que fazemos

É macaquear

A sintaxe lusíada (BANDEIRA, 1977, p.212)

Já trabalhamos essa estrofe ao nos referirmos à reconstrução da multiplicidade de fatores que o texto literário pode suscitar. Retomando as idéias de Roger Chartier (2001), é possível admitir ser a leitura uma reconstrução de normas, regras e costumes tendo em vista os atos singulares, que se situam e encontram sentido no texto literário. Esses atos, se articulam com os elementos da realidade material do mundo social, das práticas humanas que são entendidas como representação. ${ }^{11}$ Desse modo, o índice da memória pode ser visto no texto literário quando neste há práticas que traduzem a tradição cultural de um povo, demonstrando seus conflitos e valores, bem como, o registro da oralidade experienciada na ordem do discurso.

Nos versos da última estrofe de "Evocação do Recife", lemos:

A vida com uma porção de coisas que eu não entendia muito bem

Terras que eu não sabia onde ficavam

Recife...

Rua da União...

A casa do meu avó...

Nunca pensei que ela acabasse!

Tudo lá parecia impregnado de eternidade

Recife...

\footnotetext{
${ }^{11}$ Roger Chartier admite como representação algo que pode ser reconhecido como produção em materialidade (remete a algo concreto, experiência, vivência) vivência prática e não algo apresentado novamente.
} 
Meu avô morto.
Recife morto, Recife bom, Recife brasileiro como a casa de meu avô.

(BANDEIRA, 1977, p.212)

Bandeira termina por consagrar seu território quando diz que tudo na casa de seu avô parecia impregnado de eternidade. A casa avoenga, concebida em nossa análise como lugar de permissividades e travessuras, tem a mesma perenidade da escrita poética. De tão universal, tanto a casa do avô quanto a poesia não apresentam limitações geográficas, mas correspondem à memória cultural de uma nação.

O trecho referido traz a concepção divina compreendida a partir do Mito do Eterno Retorno que apanha o sentido do nível cósmico mais elevado, pois compreende que "apenas o sagrado existe de maneira absoluta, criando coisas e fazendo com que elas perdurem." (ELIADE, 2004, p.23). A poesia sacralizou o Recife da infância e da mitologia de Bandeira ao tornar universais e perenes todas as experiências.

Fica claro, em suma, que a renovação buscada pelo nosso poeta modernista foi alcançada pela ligação que a infância tem com a memória e o reino lúdico da poesia. Finalizaremos o presente estudo com as palavras de Cassiano Ricardo que, no dizer de Charles Baudelaire, arrematará o sentido que estamos atribuindo à infância na lírica do poeta em análise: “Que é a poesia, se não, a infância que se encontrou de novo?” (RICARDO, 1978, p.183).

\section{Referências}

AGAMBEN, Giorgio. Infância e história: destruição da experiência e origem da história. Belo Horizonte: Editora UFMG, 2005.

ARRIGUCCI Jr., Davi. Humildade, paixão e morte: a poesia de Manuel Bandeira. São Paulo, Companhia das Letras, 2003.

ÁVILA, Affonso. O Modernismo. 2. ed. São Paulo: Perspectiva, 2002.

BANDEIRA, Manuel Poesia completa e prosa. Rio de Janeiro: Nova Aguilar, 1977. . Estrela da Vida Inteira. Rio de Janeiro: José Olympio, 1986. . Seleta de Prosa. Rio de Janeiro: Nova Fronteira, 1997.

ANDRADE, Mário de; BANDEIRA, Manuel.Correspondência. MORAES, Marcos Antonio. (Org.) São Paulo: Editora da Universidade de São Paulo: Instituto de Estudos Brasileiros, Universidade de São Paulo, 2. ed. - 2001. (Coleção Correspondência de Mário de Andrade). 
BARBOSA, Ivone Cordeiro. Sertão: Um Lugar Incomun - O sertão do Ceará na literatura do século XIX. Rio de Janeiro: Relume Dumará; Fortaleza, CE: Secretaria de Cultura e Desporto do Estado, 2000. (Coleção Outros diálogos; 5).

BRAYNER, Sônia. "Nota preliminar". In: Manuel Bandeira: Seleção de textos. In: (org.) - Rio de Janeiro: Civilização Brasileira; Brasília: INL, 1980 (Coleção Fortuna Crítica). p. 9-10.

BENJAMIN, Walter. "Experiência e pobreza". In: Obras Escolhidas: Magia e Técnica, Arte e Política. Trad. Sérgio P. Rouanet. São Paulo: Brasiliense, 1993. p. 114-119. a.

. "O narrador". In: Obras Escolhidas: Magia e Técnica, Arte e Política. Trad. Sérgio P. Rouanet. São Paulo: Brasiliense, 1993. p. 197-221. b.

. "Sobre o conceito da História". In: Obras Escolhidas: Magia e Técnica, Arte e Política. Trad. Sérgio P. Rouanet. São Paulo: Brasiliense, 1993. p. 223-232. c.

CASCUDO, Luís da Câmara. Dicionário do Folclore Brasileiro. São Paulo: Global, 2002.

CHARTIER, Roger. Cultura Escrita, Literatura e História. Trad. ROSA, Ernani.. Porto Alegre/RS: Artmed, 2001.

DAMATTA, Roberto. O que faz o brasil, Brasil? Rio de Janeiro: Rocco, 1984.

ELIADE, Mircea. Mito do Eterno Retorno. São Paulo: Mercuryo, 2004.

FARGE, Arlete. Lugares para a história. Trad: LISBOA, Telma Costa. Editora Teorema, 1999.

FREYRE, Gilberto. "Manuel Bandeira, Recifense". In: Perfil de Euclides e outros perfis. Rio de Janeiro: José Olímpio, 1944; Manuel Bandeira: Seleção de textos - Coletânea organizada por Sônia Brayner - Rio de Janeiro: Civilização Brasileira; Brasília: INL, 1980 (Coleção Fortuna Crítica). p. 76-81.

GONÇALVES, David. Atualização das formas simples em tropas e boiadas. Rio de Janeiro: Presença, 1981.

GONÇALVES, José Moura Filho. "Olhar e memória” In: $O$ olhar. Adauto Novaes [et al.] São Paulo: Cia das Letras, 1988. p. 95-124.

HELlER, Agnes. O Cotidiano e a História. Trad. COUTINHO, Calos Nelson e KONDER, Leandro. São Paulo: Paz e Terra, 1985.

JOZEF, Bella. O resgate da memória na literatura contemporânea. In: Anais do $2^{\circ}$ Congresso da Abralic. V.1. Belo Horizonte: 1991. p. 454-460.

KRENAK, Ailton. Antes, o mundo não existia. In: NOVAES, Adauto et al.. Tempo e História. São Paulo: Companhia das Letras, 1992. p, 201-204. 
LE GOFF, Jacques. História e memória. Campinas: Ed. Unicamp, 1994.

MIGNOLO, Walter, Lógica das diferenças e política das semelhanças da Literatura que parece História ou Antropologia, e vice-versa. In: CHIAPPINI, Lígia e AGUIAR, Flávio W. Literatura e História na América Latina. São Paulo: EDUSP, 1993.

MOISÉS, Massaud. A criação literária: pura. São Paulo: Cultrix, 1983. . Dicionário de termos literários. São Paulo: Cultrix, 2004.

OLIVEIRA, Rejane Pivetta de. Literatura e História: A verdade como imaginação. In: Signo. Santa Cruz do Sul, v. 20, n. 29, p. 49-56, nov. 1995.

PENNAFORT, Onestaldo. Marginália à Poética de Manuel Bandeira. In: Homenagem a Manuel Bandeira. Rio de Janeiro, 1936; Manuel Bandeira: Seleção de textos - Coletânea organizada por Sônia Brayner - Rio de Janeiro: Civilização Brasileira; Brasília: INL, 1980 (Coleção Fortuna Crítica). p. 101-120.

PONTES, Roberto. Mentalidade e Residualidade na Lírica Camoniana. In: SILVA, Odalice de Castro e LANDIM Teoberto (orgs.) Escritos do cotidiano: Estudos de Literatura e Cultura. Fortaleza: 7 Sóis, 2003.

RICARDO, Cassiano. Martin Cererê: O Brasil dos meninos, dos poetas, dos heróis. $14^{\mathrm{a}}$ ed. Rio Janeiro: José Olympio, 1978.

ROSA, Guimarães. Grande Sertão: Veredas. São Paulo: Círculo do Livro, 1984.

VANDERLEI S., Kalina, HENRIQUE S., Maciel. Dicionário de Conceitos Históricos. São Paulo: Contexto, 2005.

VEIRA, Sulamita. Plasticidade da Linguagem Musical de Luiz Gonzaga. In: Revista de Ciências Sociais: Práticas e Representações Regionais. no 1/ 2, Universidade Federal do Ceará. 1999. p. 15-27.

WILLIAMS, Raymond. Marxismo e Literatura. Rio de Janeiro: Zahar, 1979.

ZUMTHOR, Paul. A letra e a voz. (Trad.) PINHEIRO, Amalio e FERREIRA, Gerusa Pires. São Paulo: Companhia das Letras, 1993. 